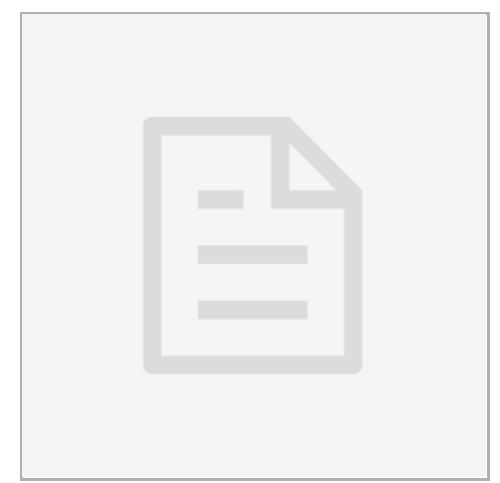

NOV 16, 2018

\section{open ठaccess}

DOI:

dx.doi.org/10.17504/protocol s.io.s38egrw

Protocol Citation: Simona Abbà 2018. Gel

Electrophoresis - TBE 0.5X. protocols.io

https://dx.doi.org/10.17504/p rotocols.io.s38egrw

License: This is an open access protocol distributed under the terms of the Creative Commons Attribution License, which permits unrestricted use, distribution, and reproduction in any medium, provided the original author and source are credited

Protocol status: Working We use this protocol and it's working

Created: Aug 29, 2018

Last Modified: Nov 16, 2018

\section{PROTOCOL integer ID:} 15200

Keywords: ethidium bromide, TBE, UV, DNA

\section{(3) Gel Electrophoresis - TBE 0.5X}

Forked from Gel Electrophoresis

Simona $\mathrm{Abbà}^{1}$

${ }^{1}$ Institute for Sustainable Plant Protection - National Research Council of Italy (IPSP-CNR)

Simona Abbà

Institute for Sustainable Plant Protection - National Resear...

\section{ABSTRACT}

Separates molecules based on size.

\section{MATERIALS}

\section{MATERIALS}

88 Ethidium P212121

881 kb DNA Ladder - 1,000 gel lanes New England Biolabs Catalog \#N3232L 89 Gel Loading Dye, Purple (6X), no SDS - $4.0 \mathrm{ml}$ New England Biolabs Catalog \#B7025S

88 TAE Buffer (Tris-acetate-EDTA) Contributed by users Catalog \#B49

88 Agarose Contributed by users Catalog \#A5304

STEP MATERIALS

88 Agarose Contributed by users Catalog \#A5304

$881 \mathrm{~Kb}$ Plus DNA Ladder Invitrogen - Thermo Fisher Catalog \#10787018

88 DNA Gel Loading Dye (6X) Thermo Fisher Scientific Catalog \#R0611

\section{SAFETY WARNINGS}

(4) Ethidium Bromide potentially acts as a mutagen or carcinogen.

\section{BEFORE START INSTRUCTIONS}

Have a DNA Sample ready, typically either from PCR or a recently performed Restriction Digest. Dilute down the 50X TAE Buffer to 1X.

\title{
Prep Work
}


1 Pour $150 \mathrm{~mL}$ of $0.5 X$ TBE Buffer into a $250 \mathrm{ml}$ Duran Bottle.

I $150 \mathrm{~mL}$ 0.5X TBE buffer

2 Weigh out $1.5 \mathrm{~g}$ Agarose and add it to the Duran bottle.

I $1.5 \mathrm{~g}$ agarose

88 Agarose Contributed by users Catalog \#A5304

3 Place Duran bottle in a microwave on medium power for two minutes or until solution is clear and agarose is completely dissolved, occasionally stirring.

(7) 00:02:00 agarose melting

4 Remove the Duran bottle from the microwave with a glove/pot holder and let it cool under tap water until you can comfortably pick it up without protection.

00:02:00 gel cooling down

$5 \quad$ Place gel tray on clamp.

Add well combs and use a level to ensure it is balanced.

Pour $40 \mathrm{ml}$ (small gel) or $70 \mathrm{ml}$ (big gel) of melted agarose into the gel tray and let it sit for 15 minutes, or until solid.

(7) 00:15:00 gel solidification

\section{Loading the Gel}

6 Remove the well comb/s carefully as to not tear the gel and remove the tray from the clamp, but ensure the gel remains in the tray.

$7 \quad$ Place the gel tray into the gel electrophoresis apparatus with the wells closer to the negative/black end.

Pour additional 0.5X TBE Buffer to fill each side of the apparatus and to create a thin layer of buffer covering the top of the gel.

Pipette $5 \mu \mathrm{L}$ of the $1 \mathrm{~kb}$ DNA Ladder with Loading Dye into a well.

Prepare your DNA samples by adding an adequate amount of Gel Loading Dye (6X) and load them into the wells. 
$881 \mathrm{~Kb}$ Plus DNA Ladder Invitrogen - Thermo Fisher Catalog \#10787018

88 DNA Gel Loading Dye (6X) Thermo Fisher Scientific Catalog \#R0611

\section{Running the Gel}

8 Place lid on apparatus and plug cables into the power supply. Set the power supply to stay at a constant voltage of $90 \mathrm{~V}$ (small gel) - $120 \mathrm{~V}$ (big gel).

Let the gel run until the bromophenol blue reaches the end of the gel

\section{Staining}

9 Remove the gel from the gel tray after draining excess of TBE Buffer.

Place gel into a tray with $1 \%$ Ethidium Bromide ensuring the solution does not come into contact with your skin, then place the tray over a shaker with gentle agitation.

Let the gel stain for 15 minutes.

\section{0:15:00}

\section{Destaining}

10 Carefully remove the gel from the Ethidium Bromide solution and place it ina tray with distilled water, then place the tray over a shaker with gentle agitation.

Let the gel destain for $10 \mathrm{~min}$

\section{UV exposure}

11 Place the gel on top of a UV light source with a camera.

Turn on the UV light and capture a picture of the gel. 